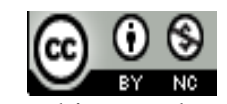

Journal of Education, Teaching, and Learning is licensed under

a Creative Commons Attribution-Non Commercial 4.0 InternationalLicense.

\title{
CONDition OF ISLAMic EdUCATION In KoKOdA AT MAEbo TribE Village, Village Klabinain, Aimas District, Sorong
}

\author{
Sukman S \\ STAIN Sorong, Indonesia \\ E-mail: sukmanstainsorong@gmail.com
}

\begin{abstract}
This study was conducted to investigate the implementation process of Islamic religious education in the public sphere Kokoda. Especially those living in Maebo Village, Sorong, West Papua. Further study is intended to look at the obstacles faced by educators in performing their duties in Maebo Village. This research was conducted with qualitative methods by interviewing objects associated with the process in the field. Based on the facts obtained, this study reveals several things, such as: first, from existing educational facilities, in new Maebo village has a primary school run by a private foundation. Only state schools still require education personnel can continue to carry out the activities of the school. Second, the constraints faced by the people in the village of Kokoda Maebo in studying is their own consciousness. The majority of children are still more concerned with work than school. This is attempted to be addressed by teachers in order that future generations Kokoda existing communities can the better quality of life.
\end{abstract}

Keywords: Education Kokoda, Sorong, West Papua.

\section{INTRODUCTION}

Sorong, in addition to having potential tourism and industry, also has a wealth of culture possessed by each tribe who inhabit it. One tribal community in Sorong is the tribe of Kokoda. Kokoda tribe came from the South Sorong. Precisely in the area Inanwatan and Teminabuan. Kokoda tribe looking for a decent living in Sorong to create their own villages located at Km. 8 Sorong (Arifin, 2017). Kokoda tribe turned the wheel of life by breaking stone and wood gathering. As for the other residents are fishermen and construction workers. All residents Kokoda participate actively so that a high work ethic have been entrenched in society Kokoda (Wekke and Sari, 2017).

Kokoda is a minority tribe in Sorong known for Islam majority in it. Islam itself has known since about 1916. The spread of Islam in parts of the kingdom of Tidore Kokoda started by the authorities in the area of Kokas. Among the kings of Coke, a king Patipi, Raumbati King, and the King of whales, they carry out the trade and the spread of up to Kokoda area (Wekke and Sari, 2017). Coke is an area in the consortium, West Papua.

In 2013, together with the airport development project Domini Eduard Osok, Kokoda tribe splintered into small parts. One of these tribes Kokoda housed in Jalan Poros Klalin 4, Maebo Village, Klabinain, Aimas. With 87 heads of families were registered, the state of these tribes can still be said to be so far behind. One of the causes includes obstacles collection. The problems began a birth certificate data to other population is still less noticed by the community itself Kokoda (Hidayah, 2017). Though the data is an important aspect in determining the beneficiaries to be clear procedures in the production of financial statements.

Channeling aid to Kokoda society is still far from the target. This arises from incomplete data on population so that the distribution of aid was unclear goals (Fatima, 2017). This makes those who do not know anything about it will issue no injustice assess aid.

In the homogeneity deficiencies, there is an excess of Kokoda society. Ie able to live together with people of other faiths, without causing conflict. The way in which this time there are three things. First, integrate perception that brotherhood above everything. Second, establish cognitivity (understanding) they found thick and shared. Third, preserve and maintain the tradition (heritage) ancestors, mainly sourced from local wisdom (Rais, 2009). With the understanding as it is commonly called plurality, Kokoda society can maintain unity and integrity within their own tribe. Understand here that are actually needed by each community in Indonesia, especially people who inhabited by ethnic Sorong heterogeneous nation. 
Education is the basis of development of a country. Not to forget also education in Sorong. Sorong is a town in the province of West Papua. To know in Sorong education can not only be judged from excellent schools only. But keep in mind also study the outlying villages. One was an education in the village inhabited Maebo Kokoda ethnic groups. The elementary school is the only formal education in this village. While the non-formal education is done in the mosque in the village. Formal education is structured and tiered educational status of public and private comprised of early childhood education, elementary education, secondary education and higher education (Anggriani, 2011). While non-formal education is education that is done without attachment to the hierarchy that is usually offered programs that are needed by the community at the time (Maulida, 2012).

Education for Kokoda rate is still not a top priority. This phenomenon is evidenced by the attendance rate of the tides (Arifin, 2017). This makes the educators in Maebo Village seeks to constantly pick up the ball so that parents support their children to school. There are various reasons why people still do not prioritize education Kokoda. One of the main economic problem that they still have to deal with so most of them to work more productive than in school (Hidayah, 2017). Several reasons prompted the authors to focus on researching more about how people's lives Kokoda, the existing education and how the public response to the existing educational Kokoda.

\section{DISCUSSION}

\section{A. description of the Muslim Community in Maebo Kokoda Tribe}

Kokoda is one of the sub-tribe of Imeko, a native of South Sorong Regency, West Papua. Kokoda consisting of various villages that stayed in the area, such as Kasueri Village, Wigori, Taroe, Tambani, Udagaga and Menawaturi. Of the various neighborhoods is then incorporated into the tribe Kokoda and the languages namely Yamueti. Kokoda word has the meaning ascribed Yamueti language, namely the black water around him are sago palms surrounding the water area (Wekke and Sari, 2017). In the tradition of Kokoda, known leadership system that reigned as a leader who inherited and led by a king. King enthroned in the highest position and below it is the functionaries, such as traditional leaders who have a role in rectifying the language used in everyday life in order not contaminated by other languages and preserve their traditions (Wekke and Sari, 2017). The role of keeping the culture as is normal in every tribe in Indonesia. Generally, they called this culture to be a place to ask about solving the problems that occur in a community.

Kokoda tribe itself is a newcomer in Sorong. At first, tribes settled in Kokoda in Sorong Sorong KM 8 before exposure to the eviction during the construction of the airport Eduard Osok Domini. The layout of the township that is very close to the runway is very dangerous both for people Kokoda, as well as the airline itself. This has forced the government to relocate villages Kokoda Kokoda so the tribe is now fragmented location.

One location is in the village of Kokoda tribe Maebo, Klabinain, Aimas. As noted Principal MI Al Ma'arif 1, relocating people to the village of Kokoda Maebo an initiative of the village head (Arifin, 2017) The reason is that before their homes were demolished as part of community groups Kokoda has been used to look for wood and stone near Maebo Village, This suggests that the tribe is not Kokoda community can only hope for aid, but they are still struggling in difficulties so that their existence is still there to this day. Maebo Village condition is still very far from comfortable terms. Located in swampy areas, there is no source of clean water in the village. Similarly, the electricity network. People still rely on candles for lighting at night their activities mushalla exception that has been put on the generator. The use of candles as home lighting is very dangerous because most of the houses in Maebo Village walled timber so that in case of fire, would bring huge losses.

Seeing the conditions that exist, in 2015 the central government through the Ministry of Social Affairs to provide assistance in the form of 60 social houses in the community in the village of Kokoda Maebo but there is still a shortage of local government budget finally close the shortfall. The amount of aid is still not in accordance with the number of families that exist. The reason is that data collection is constrained by letters of the population that have not all owned by each family (Hidayah, 2017).

The Cultural and religious element is very important and present in every culture tribes. Similarly, the rate Kokoda. Disclosed by Elementary School Principal Al Ma'arif 1 is justified by the village head Maebo that Islam has been known since the time of their ancestors and Islamic Kokoda tribe that now is not a new convert, but already they have known since the birth of Islam. This is reinforced by the results of research that suggests that Islam has been recognized by Kokoda rate since 1916 through trade and the propaganda carried Tidore kingdom (Wekke and Sari, 2017).

Kokoda tribe is generally an open rate on new things and are very receptive to the presence of foreigners in their midst. This is indicated by the friendliness of Kokoda in the vacancy rate from outside their group, and some have been married to migrants from the island of Java. It shows the Kokoda culture has also been accepted by the outside community.

\section{B. Conditions in the village of Kokoda Tribe Education Maebo}

Since the days of Nabi Ibrahim, houses of worship have become the center of human civilization. This phenomenon continues until the finisher religion brought by Nabi Muhammad saw. named Islam. At the time of Muhammad Rasulullah, in addition to the construction of mosques as a place of worship, is also intended as a center of education and socio-economic. The role of the mosque as a center of education and teaching is always open to anyone who feels capable and able to provide or teach his knowledge to those 
who thirst for knowledge (Rahman, 2015). Education in this mosque applies the principle of equal opportunity for all Muslims who wish to seek knowledge without distinction of socio-economic status of students. They have the freedom to choose the subjects of subjects she wants, even freely voting for the teacher (Soekarno and Supardi, 1990). This theory suggests that the mosque should be non-formal education centers.

Since its founding in 2013, the village has a mosque Maebo named Mosque Al-Jabar. This mosque at its inception is a non-formal education center at once formal education for the public emergency Maebo Kokoda village. Formal education programs initiated by the organization IPNU (Nahdlatul Ulama Student Union) and IPPNU (Princess Nahdlatul Ulama Students Association) (Suyatedja, 2017). As for the non-formal education is a form of NU's program for their routine. Activity is the general study iqra programmed routinely performed on Tuesday (Fatima, 2017). These programs demonstrate the community's role in assisting the reconstruction sliding Kokoda tribal life after massive relocation not only the infrastructure but also help to reconstruct the mental from Kokoda tribe.

In 2014, IPNU and IPPNU assisted Kokoda building society specifically for schools (Suyatedja, 2017). Maebo school building in the village is not as generally complete by the teacher's room, a study table to the field. The condition of existing school just a place to conduct classes in order to separate the building with the Mosque of Al-Jabar located next door. School made structure located above the stage as the swamp and made with wood for walls and pillars. With its limitations, the school has been registered in Kemendikbud with NPSN (National Statistical Identification Number) 69,854,718 under the name SD Al Ma'arif 1 Klabinain as a private school run by the Institute of Education Al Ma'arif NU Sorong (PDSP-K, 2017),

In the service, the highest grade in elementary Al-Ma'arif new 1 up to grade 5 . The students are actively participating in school activities until now consists of 48 children (Arifin, 2017). While the teachers who teach in elementary $\mathrm{Al}$ Ma'arif 1 active only one person who serves as Principal; Zainal Arifin, S. Sos. In addition, there are other teachers, but less active in teaching. The teacher from Kokoda own community numbered 2 and in addition, there are also volunteers from various universities who assist in the learning process does not necessarily amount (Arifin, 2017). For comparison, the data SD Al Ma'arif 1 taken from the database of the Ministry of Education and Culture, teachers and education staff (PTK) amounted to 6 with details of 2 men and 4 women (http: //dapo.dikdasmen.kemendikbud .go.id / s).

In addition to the school in the morning, there is also a landfill that teaches the Koran to children. The number of students at the school in the morning. The reason for parents who have consciously with the importance of education is not half-hearted in his reign so that not only school in the morning, but for landfill parents also support their children to keep learning (Hidayah, 2017).

\section{Problems of Education At Kokoda tribe in Maebo Village}

Based on conditions on the ground, the author has formulated the main problems in education in the tribal village of Kokoda in Maebo. Among other issues on the mindset of the people, facilities, and infrastructure, to the limitations of the motor of society that affect less the standalone community towards educational activities.

Given the limitations of existing, and building a makeshift school, elementary manager Al Ma'arif 1 Klabinain continue to take the children to school Kokoda. Kokoda public awareness on the importance of education Maebo Kampung still not evenly distributed. Most are still more concerned about the economy than education (Arifin, 2017). Indeed, if viewed the situation, the economy is still the biggest problem people Kokoda. But without cared from government public education will not necessarily bring an increase for them.

The family is the smallest social unit consisting of father, mother, and child. Environment relating to the child are his parents, brothers, and sisters who are older, and probably close relatives who live at home. Through the environment, the child will get to know the surrounding world and the prevailing pattern of social life every day. The family also has multiple functions for the creation of social life in the community. In the family, set up the relationship between the members so that each family member has a clear role and function (Rezty, 2017). The family is the first school for a child. The formation of personality, morals and doctrinal inculcated from childhood by parents. Unfortunately, the role of parents in their children's education Kokoda considered less active. Examples such as not firmly remind their children to school (Arifin, 2017). This condition according to the elementary school principal of Al Ma'arif 1 rated on the attendance of students coming to school are still ups and downs. But when approached at his home, the parents claimed to have warned their children to school.

With public awareness of such conditions would not want any effort by schools to attract the enthusiasm to want to go to school. Including finding materials that fit their abilities (Arifin, 2017). This policy according to the author taken apart due to the limited ability of students to absorb the lessons, also with limited teacher made school will be overwhelmed if the guidelines. Regarding the limited ability of the students, Fahmi Anggraini Suyatedja, describes his experience teaching in class V, "My time for the group to work tasks, there is one group that is very long to do it, when I asked it turns out no one knows because what because they cannot read," said he laughed when found in Klabinain (Suyatedja, 2017).

Non-formal activities were initially launched by walking routine and carried out by local self. Kokoda himself was the fact that there limping. The enthusiasm of the public only at the beginning of it. Lack of religious leaders living of the people also give a feel of religious aridity. As a result, many are not able to read the Qur'an (Hidayah, 2017). Religious activities in Maebo Village as of Isra 'Mi'raj, recitals, and warning other big days still requires lighters from outside the 
village. Without an outsider who run religious activities, none of which run from the village (Arifin, 2017). However, when there are traditional events like naming a baby or death, the community took the initiative to do it yourself.

The lack of religious events by the author cannot be separated from the existing culture. Kokoda tribe are maintaining their culture is evidenced by the traditional leaders who maintain traditional values of outside influences. So as to enable religious activities to have to fit into their culture. One of the religious practices that have entered into the culture of Kokoda is Tifa Syawat. That is an art of the area Kokas (the consortium) carried by preachers to spread Islam in the form of harmony Kokoda Papua typical wasp music to accompany readings sholawat ((Wekke and Sari, 2017). This proves that in order to develop the necessary Islamic Kokoda person who can cultured and civilizing Islam without compromising the cultural values Kokoda itself. to achieve this mission, it takes education to cultivate the seeds of the successor cultures Kokoda through their children. Therefore enlightenment to parents the importance of education should be encouraged because quality seeds derived from a superior parent or can be seeded anyway. With his conscious education, gradually the development of various fields in parts Kokoda will increase along with the quality of education in Maebo Village that continues to improve. to improve the quality of education, not in spite of the role of universities to spawn kan competent educators who would have to continue to expand education to places like Maebo Village backward with learning programs and volunteer program. The hope is not to miss the role of local government and community institutions in building infrastructure in Maebo Village that the community helped in reducing the difficulties of their lives.

\section{CONCLUSIONS}

Based on the facts found, that the level of public awareness of the importance of education Kokoda quite low. This makes the authors draw the conclusion that the source of all the problems is the lack of awareness of yourself. In this case, the determining whether or not the condition will progress Kokoda society is their own consciousness. Outside the community cannot always help. One time they had to stand on their own feet.

\section{REFERENCES}

Anggraini, Rika. (2011). Schools as Formal Education Institution. Bandar Lampung: Lampung University papers.

Rahman, F. (2015). Alfan Islamic History at the Umayyad period. Sorong: STAIN Sorong, paper.

Rais Muhammad. (2009). Relation of Religion and Local Wisdom: Study of Religious Ideology Etnosains to Inclusiveness Community Kokoda, Papua Barat. Sorong: STAIN Sorong, a research proposal.

Sekha Maulida, Nur. (2012). Non-Formal and Informal Education. Malang: The Malang Islamic University, papers.

Ahmad Sukarno and Supardi. (1990). History and Philosophy of Islamic Education. Bandung: Space.

\section{Internet Resources}

Ministry of Education and Culture. Basic Data Elementary and Secondary Education: Elementary Al Maarif 1 Klabinain Sorong. http://dapo.dikdasmen.kemendikbud.go.id/sekolah/ 66EB2BDA55690022227E (accessed May 7, 2016)

Wekke, Ismail Suardi and Sari, Yuliana Ratna. (2016). TifaEntities Syawat and Propagation in the Islamic Cultural Studies Kokoda Tribe Sorong in West Рapua, ebook, http://journal.uinsuka.ac.id/jurnal/artikel/207/tifa-syawat-danentitas-dakwah- deep-Islamic cultural-studiestribe-Kokoda-sliding-Papua-west. (downloaded 25 April 2016).

Data and Statistics Education - Culture (PDSP-K) of the Ministry of Education and Culture. Education Reference Data. http://referensi.data.kemendikbud.go.id/index11.ph p?kode $=320714 \&$ level=3 (accessed May 6, 2016).

Rezty, Rahita. The design of Qualitative Research Methods: The Role of Parents in Parenting, http://rezyoung.blogspot.com/2015/05/proposalperan-orang-tua-dalam-mengasuh.html (accessed May 6, 2016).

\section{Source Interview}

Fatimah, Francine. Chairman of NU's Women Sorong, on May 5, 2016.Mayamuk,

Suyatedja Fahmi Anggraini. Chairman IPPNU Branch District. Sorong period 2014-2015 and teachers in elementary Al Ma'arif 1 Klabinain in Maebo, May 4, 2016.

Hidayah, Nurul Iga. Teachers in elementary Al Ma'arif 1 Klabinain, in Maebo, May 4, 2016.

Arifin Zainal. Elementary School Principal Al Ma'arif 1 Klabinain, in Maebo, May 4, 2016. 